\title{
PENETAPAN KADAR IBUPROFEN DALAM TABLET SERTA APLIKASINYA PADA PLASMA TIKUS JANTAN WISTAR SECARA IN VITRO DENGAN METODE KCKT
}

\section{DETERMINATION OF IBUPROFEN TABLETS IN WISTAR RAT PLASMA MATRIX BY HPLC}

\author{
Susanti, Aditya Hanif Evridianto, Ika Diandana Yulia Asmara, \\ Asmiyenti Djaliasrin Djalil \\ Fakultas Farmasi Universitas Muhammadiyah Purwokerto, \\ Jl. Raya Dukuhwaluh, PO BOX 202, Purwokerto 53182
}

\begin{abstract}
ABSTRAK
Telah dilakukan penelitian mengenai pengembangan metode KCKT dalam penetapan kadar tablet ibuprofen dalam plasma darah tikus jantan wistar secara in vitro. Metode divalidasi berdasarkan parameter linearitas, akurasi, dan presisi. Kondisi KCKT yang digunakan adalah fase terbalik dengan kolom shim pack CLC ODS dan fase gerak asetonitril:bufer fosfat $(35: 65 \mathrm{v} / \mathrm{v})$, laju alir $0,8 \mathrm{~mL} / \mathrm{min}$. Hasil uji linearitas menunjukan nilai $\mathrm{r}=0,993$ pada kisaran konsentrasi 0,5-5 $\mu \mathrm{g} / \mathrm{mL}$, presisi 0,93 (\%RSD), dan perolehan kembali 92,9\%. Penentuan ibuprofen dalam tablet generik dan merek pada matriks plasma tikus jantan wistar menghasilkan persen kadar pada kisaran antara 80100\%. Telah dilakukan penelitian mengenai pengembangan metode KCKT dalam penetapan kadar tablet ibuprofen dalam plasma darah tikus jantan wistar secara in vitro. Metode divalidasi berdasarkan parameter linearitas, akurasi, dan presisi. Kondisi KCKT yang digunakan adalah fase terbalik dengan kolom shim pack CLC ODS dan fase gerak asetonitril:bufer fosfat $(35: 65 \mathrm{v} / \mathrm{v})$, laju alir $0,8 \mathrm{~mL} / \mathrm{min}$. Hasil uji linearitas menunjukan nilai $\mathrm{r}=0,993$ pada kisaran konsentrasi $0,5-5 \mu \mathrm{g} / \mathrm{mL}$, presisi 0,93 (\%RSD), dan perolehan kembali 92,9\%. Penentuan ibuprofen dalam tablet generik dan merek pada matriks plasma tikus jantan wistar menghasilkan persen kadar pada kisaran antara 80$100 \%$.
\end{abstract}

Kata kunci: HPLC, ibuprofen, in vitro, plasma, validasi

\section{ABSTRACT}

HPLC (High Performance Liquid Chromatography) method has been developed and validated for analysis of ibuprofen tablets in plasma male wistar rat in vitro. The developed method was validated with respect to linearity, accuracy, and precision. RP-HPLC analysis was carried out using shim pack CLC ODS column and mobile phase was composed of acetonitrile and phosphate buffer $(35: 65 \mathrm{v} / \mathrm{v})$, at a flow rate of 0.8
$\mathrm{mL} / \mathrm{min}$. The method gave excellent linearity $(r=0.993)$ in the concentration range of $0.5-5 \mu \mathrm{g} / \mathrm{mL}$, precision was 0.93 (\%RSD), and mean recovery was found $92.9 \%$ which showed accuracy of the method. Determination of ibuprofen generic and brand-name tablets in male wistar rat plasma in vitro were in the range of $80-100 \%$.

Keywords : HPLC, ibuprofen, in vitro, plasma, validation 


\section{PENDAHULUAN}

Obat merupakan zat yang digunakan untuk diagnosis, mengurangi rasa sakit, serta mengobati atau mencegah penyakit pada manusia atau hewan (Ansel, 1985). Salah satu obat yang digunakan sebagai antiradang dan analgesik adalah ibuprofen.

Ibuprofen

(Gambar merupakan obat analgetik golongan NonSteroid Anti-Inflammatory drugs (NSAIDs) turunan asam arilasetat. Obat ini terutama digunakan untuk mengurangi rasa nyeri akibat peradangan pada berbagai kondisi rematik dan arthritis. Ibuprofen menimbulkan efek analgesik dengan menghambat secara langsung dan selektif enzim-enzim pada sistem saraf pusat yang mengkatalis biosintesis prostaglandin seperti siklooksigenase. Penghambatan tersebut menyebabkan pencegahan sensitasi reseptor rasa sakit oleh mediatormediator rasa sakit seperti bradikinin, histamin, serotonin, prostasiklin, prostaglandin, ion hidrogen dan kalium yang dapat merangsang rasa sakit secara mekanis atau kimiawi (Katzung, 2001; Siswandono dan Soekardjo, 2000).

Ibuprofen telah banyak diproduksi oleh berbagai pabrik farmasi dengan berbagai nama dagang. Oleh sebab itu diperlukan metode analisis yang baik untuk menganalisis kandungan ibuprofen tersebut. Tujuan penelitian ini adalah mengembangkan metode analisis ibuprofen dan aplikasinya dalam tablet generik, merek pada matriks plasma tikus wistar jantan.

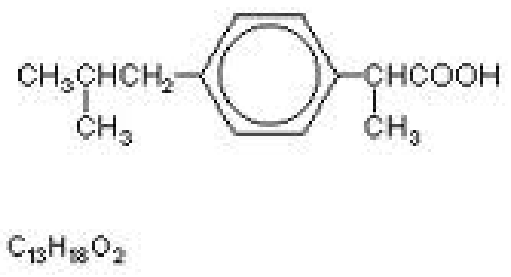

Gambar 1. Struktur ibuprofen (Depkes, 1995).
Kromotografi Cair Kinerja Tinggi (KCKT) dikembangkan pada akhir tahun 1960-an dan awal tahun 1970-an. Kegunaan umum KCKT adalah untuk pemisahan sejumlah senyawa organik, anorganik, maupun senyawa biologis, analisis ketidakmurnian (impurities), analisis senyawa-senyawa tidak mudah menguap (non-volatil), penentuan molekul-molekul netral, ionik, maupun zwitter ion, isolasi dan pemurnian senyawa, pemisahan senyawa-senyawa dalam jumlah sekelumit, dalam jumlah banyak, dan dalam skala proses industri. KCKT dapat digunakan baik untuk analisis kualitatif maupun kauntitatif (Gandjar \& Rohman, 2007).

Validasi metode pada penetapan
kadar ibuprofen secara in vitro
menggunakan matriks plasma darah
tikus jantan wistar sebagai hewan
percobaan perlu dilakukan untuk
mendapatkan metode valid yang dapat
dipercaya pada penetapan kadar
ibuprofen secara in vivo (studi
farmakokinetika dan uji bioavalibilitas-
bioekivalensi) maupun uji klinis pada
manusia.

\section{METODOLOGI PENELITIAN}

\begin{abstract}
Alat
Seperangkat alat kromatografi cair kinerja tinggi (Shimadzu LC-10 ATVP), detektor UV-VIS SPD 10 A, kolom KCKT: shimpack CLC ODS (M) dengan panjang $25 \mathrm{~cm}$, diameter 4,6 $\mathrm{mm}$, dan ukuran $5 \mu \mathrm{m}$, Filtration unit for KCKT (Whatman), seperangkat alat gelas (Pyrex), neraca analitis (Shimadzu® AY 220), pH meter (Metrohm), sonikator (Branson 1510), sentrifuge, vortex, jarum suntik ujung tumpul, holder tikus, pisau bedah.
\end{abstract}

\section{Bahan}

Ibuprofen baku (PT. Global Chemindo Megatrading, diperoleh dari 
PT. Phapros), ibuprofen generik dan merek, kalium dihidrogen fosfat (Merck), natrium hidroksida (Merck), EDTA, asetonitril (Merck) dan akuabidestilata (Otsuka).

\section{Prosedur Penelitian}

\section{Pembuatan Dapar Fosfat pH 7}

Larutan dapar fosfat dibuat dengan mencampur $125 \mathrm{~mL}$ kalium dihidrogen fosfat $0,2 \mathrm{M}$ dengan 111,25 $\mathrm{mL}$ natrium hidroksida $0,2 \mathrm{~N}$. Larutan diencerkan dengan akuabidestilata hingga 500,0 mL. $\mathrm{pH}$ larutan diatur hingga mencapai $\mathrm{pH} 7,0$.

\section{Pembuatan Fase Gerak}

Fase gerak yang digunakan adalah campuran dapar fosfat-asetonitril dengan perbandingan 65:35. Fase gerak dibuat dengan mencampurkan asetonitril $175 \mathrm{~mL}$ dengan dapar fosfat $325 \mathrm{~mL}$. Kemudian disaring dan disonifikasi selama \pm 15 menit (Wiria dan Suyatna, 2007).

\section{Pembuatan Larutan Stok Ibuprofen}

Sebanyak $10 \mathrm{mg}$ ibuprofen baku ditimbang seksama dan dimasukkan ke dalam labu takar $100 \mathrm{~mL}$. Ibuprofen ditambahkan dengan fase gerak sampai tanda, sehingga didapat larutan baku ibuprofen dengan konsentrasi 100 $\mu \mathrm{g} / \mathrm{mL}$.

\section{Pembuatan Kurva Baku}

Larutan stok ibuprofen diencerkan dengan fase gerak sehingga diperoleh deret standar dengan konsentrasi 0,$5 ; 1 ; 1,5 ; 2 ; 3 ; 4$ dan 5 $\mu \mathrm{g} / \mathrm{mL}$. Larutan tersebut masing-masing diinjeksikan ke alat KCKT sebanyak 20 $\mu \mathrm{L}$ dengan kecepatan alir fase gerak 0,8 $\mathrm{mL} / \mathrm{menit}$. Detektor diatur pada panjang gelombang $225 \mathrm{~nm}$. Kemudian persamaan kurva baku ditentukan dari hubungan antara konsentrasi dengan luas area yang ditunjukkan oleh kromatogram.

\section{Validasi Metode Analisis (Harmita, 2004)}

\section{Uji Linearitas}

Kurva baku yang diperoleh dari hubungan antara konsentrasi dengan luas area Larutan standar ibuprofen konsentrasi 0,$5 ; 1 ; 1,5 ; 2 ; 3 ; 4$; dan 5 $\mu \mathrm{g} / \mathrm{mL}$, dianalisis linieritasnya. Sebagai parameter adanya hubungan linear digunakan koefisien korelasi (r) pada analisis regresi linear $\mathrm{y}=\mathrm{bx}+\mathrm{a}$.

\section{Uji Ketelitian (Precision)}

Sebanyak $20 \mu \mathrm{L}$ larutan standar ibuprofen $4 \mu \mathrm{g} / \mathrm{mL}$ diinjeksikan ke alat KCKT menggunakan fase gerak dengan kecepatan alir $0,8 \mathrm{~mL} /$ menit. Pengukuran diulang sebanyak 6 kali, kemudian dicatat luas areanya dan dihitung koefisien variasinya. Rumus perhitungan koefisien variasinya :

$$
\begin{gathered}
S D=\frac{\sqrt{\sum\left(\mathrm{xi}-\mathrm{x}^{2}\right)}}{\mathrm{n}-1} \\
K V=\frac{\mathrm{SD}}{\mathrm{x}} \times 100 \%
\end{gathered}
$$

\section{LOD (Limit of Detection) dan LOQ (Limit of Quantification)}

LOD dan LOQ dihitung secara statistik melalui garis linear dari kurva kalibrasi (Harmita, 2004). Dengan kurva kalibrasi tersebut dapat dihitung LOD yaitu $\mathrm{y}=\mathrm{a}+\left(3 \mathrm{x} S_{b}\right)$. Nilai a, merupakan titik potong hasil hitungan (respon blanko). Nilai $S_{b}$ sebagai pengganti nilai dari persamaan :

$$
S_{b}=\frac{S_{y}}{x} x \sqrt{\frac{\Sigma x^{2}}{n x \sum\left(x-x^{2}\right)}}
$$

dimana:

$$
\frac{S_{y}}{x}=\sqrt{\frac{\Sigma\left(y-y^{2}\right)}{n-2}}
$$

Untuk menentukan LOQ maka nilai y pada LOQ dengan persamaan $y=a+\left(10 x S_{b}\right)$, maka LOQ dapat di hitung (Miller and Miller, 1991). 


\section{Uji Ketepatan (Accuracy)}

Uji perolehan kembali dibuat dengan metode adisi menggunakan sampel cairan biologis yaitu darah. Sebanyak 0,5 $\mathrm{mL}$ sampel darah diambil dari bagian vena ekor tikus, ditambah dengan larutan baku ibuprofen $40 \mu \mathrm{g} / \mathrm{mL}$ sebanyak $1,0 \mathrm{~mL}$, kemudian ditambah EDTA $1 \%$ sebanyak $0,5 \mathrm{~mL}$, asetonitril $0,5 \mathrm{~mL}$ selanjutnya divortex dan disentrifuge selama 10 menit dengan kecepatan $3000 \mathrm{rpm}$. Sebanyak $0,2 \mathrm{~mL}$ supernatan kemudian injeksikan ke KCKT sebanyak $20 \mu \mathrm{L}$. Dilakukan replikasi sebanyak 3 kali. Perolehan kembali dihitung dengan rumus berikut:

\author{
Recorvery $=\frac{\text { kadar terukur }}{\text { kadar teoritis }} \times 100 \%$

\section{Penetapan Kadar Ibuprofen Tablet Merek dan Generik}

\section{Keseragaman Bobot}

Dua puluh tablet ibuprofen ditimbang, dihitung bobot rata-rata tiap tablet. Jika ditimbang satu persatu, tidak boleh lebih dari dua tablet yang masingmasing bobotnya menyimpang dari bobot rata-ratanya lebih besar dari harga yang ditetapkan kolom A, dan tidak satu tablet pun yang bobotnya menyimpang dari bobot rata-ratanya lebih dari harga yang ditetapkan kolom B (Depkes, 1995).

Tabel 1. Syarat penyimpangan bobot tablet dalam Farmakope Indonesia

\begin{tabular}{lcc}
\hline Bobot rata- rata & \multicolumn{2}{c}{ Penyimpangan bobot rata-rata dalam \% } \\
\cline { 2 - 3 } & A & B \\
\hline 25 mg atau kurang & 15 & 30 \\
25 mg sampai dengan $150 \mathrm{mg}$ & 10 & 20 \\
$151 \mathrm{mg}$ sampai dengan $300 \mathrm{mg}$ & 7,5 & 15 \\
Lebih dari 300 mg & 5 & 10 \\
\hline
\end{tabular}

\section{Penetapan Kadar Ibuprofen (Wiria dan Suyatna, 2007)}

Dua puluh tablet yang memenuhi keseragaman bobot digerus hingga halus dan homogen. Serbuk yang homogen ditimbang setara dengan $20 \mathrm{mg}$ ibuprofen, dimasukkan labu takar 100 $\mathrm{mL}$, dilarutkan dengan fase gerak hingga $100 \mathrm{~mL}$. Larutan tersebut disaring dengan saringan berpori $0,45 \mu \mathrm{m}$. Kemudian diambil sebanyak $0,5 \mathrm{~mL}$ dilarutkan dengan fase gerak hingga 10 $\mathrm{mL}$ didapat konsentrasi $10 \mu \mathrm{g} / \mathrm{mL}$. Untuk penetapan kadar diambil sampel plasma sebanyak $0,5 \mathrm{~mL}$ ditambah dengan larutan stok sampel ibuprofen 10 $\mu \mathrm{g} / \mathrm{mL}$ masing-masing penambahan 0,6 ;
0,8 dan $1 \mathrm{~mL}$ dalam tabung mikro. Selanjutnya larutan ditambah asetonitril $1 \mathrm{~mL}$, divortex selama 1 menit dan disentrifugasi selama 10 menit dengan kecepatan 3000 rpm. Supernatan diinjeksikan ke KCKT sebanyak $20 \mu \mathrm{L}$. Analisis sampel masing-masing dilakukan dengan replikasi 3x.

\section{HASIL DAN PEMBAHASAN}

Hasil analisis ibuprofen dengan KCKT menunjukkan kromatogram yang dapat dilihat pada Gambar 2. Waktu retensi ibuprofen adalah pada 3,7-3,8 menit. Data kisaran waktu retensi ibuprofen dihasilkan dari beberapa pengukuran. 


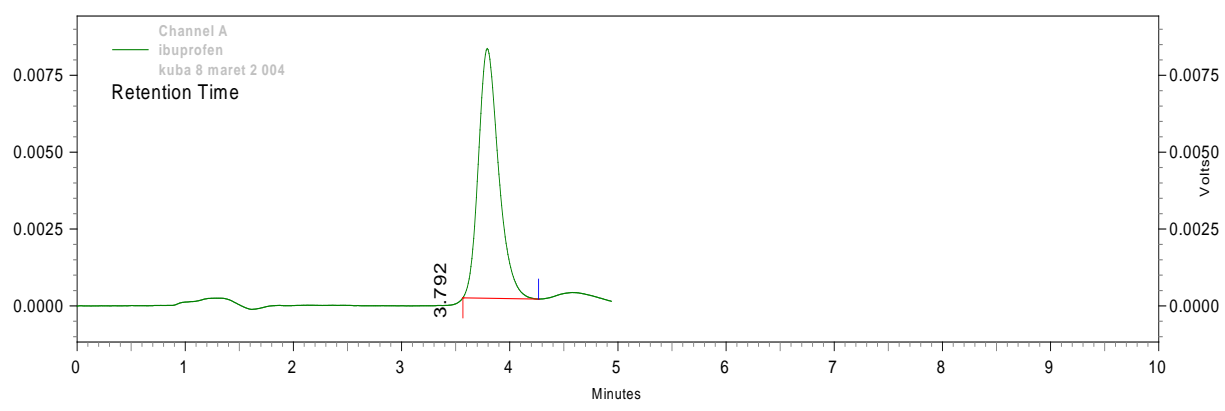

Gambar 2. Kromatogram larutan standar ibuprofen konsentrasi $2 \mu \mathrm{g} / \mathrm{mL}$.

\section{Uji Linearitas}

Kurva baku larutan standar ibuprofen dapat dilihat pada Gambar 3.

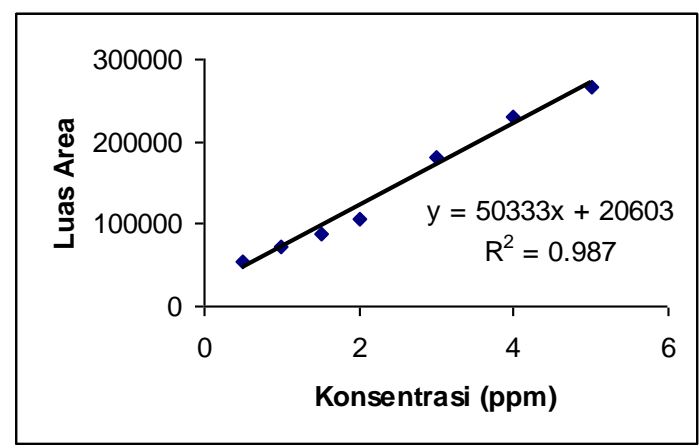

Gambar 3. Kurva hubungan konsentrasi ibuprofen dengan luas area.

Persamaan kurva baku yang diperoleh adalah $Y=50332 x+20603$ dengan nilai $\mathrm{r}^{2}=0,987$ dan $\mathrm{r}=0,993$. Nilai $r$ merupakan nilai koefisien korelasi. Hubungan linear yang ideal dicapai jika $r=1$ atau $r=-1$ karena ketika $\mathrm{r}=1$ atau $\mathrm{r}=-1$ maka terjadi hubungan yang proposional antara konsentrasi dan luas area tergantung pada arah garis (Harmita, 2004). Ini berarti bahwa nilai $r$ mendekati ideal dan persamaan yang dihasilkan dapat digunakan untuk penetapan kadar ibuprofen.

\section{Uji Ketelitian (Precision)}

Presisi dapat diukur dari nillai simpangan baku atau simpangan baku relatif (koefisien variasi). Kriteria presisi diberikan jika metode memberikan koefisien variasi (KV) $2 \%$ atau kurang. Harga KV $<2 \%$ dapat dikatakan bahwa metode tersebut memberikan presisi yang baik (Harmita, 2004).

Tabel 2. Hasil uji presisi

\begin{tabular}{cccc}
\hline Replikasi & Luas Area & $x-\bar{x}$ & $(x-\bar{x})^{2}$ \\
\hline 1 & 223838 & -538 & 289444 \\
2 & 224229 & -147 & 21609 \\
3 & 222711 & -1665 & 2772225 \\
4 & 226454 & 2078 & 4318084 \\
5 & 221817 & -2559 & 6548481 \\
6 & 227209 & 2833 & 8025889 \\
\hline Rata-rata & $\bar{x}=224376$ & & \\
Jumlah & & & \\
SD & & 2096,46 & \\
RSD & & $0.93 \%$ & \\
Ketelitian alat & & & \\
\hline & & &
\end{tabular}


Dari hasil perhitungan (Tabel 2) didapatkan nilai SD (Standar Deviation) $=2096,5$ dan RSD (Relative Standar Deviation) $=0,93 \%$ dan nilai ketelitian alat sebesar 99,07\%. Hasil yang diperoleh menunjukkan bahwa metode ini memiliki ketelitian yang masih diterima. Dari hasil perhitungan didapat nilai $\mathrm{KV}=0,93 \%$. Ini berarti berarti bahwa ketelitian penetapan kadar ibuprofen dalam plasma tikus secara in vitro dengan metode KCKT memenuhi syarat ketelitian (Harmita, 2004).

\section{Batas Deteksi (LOD) dan Batas Kuantitasi (LOQ)}

Batas deteksi (LOD) adalah jumlah terkecil analit dalam sampel yang dapat dideteksi yang masih memberikan respon signifikan dibandingkan dengan blangko. Merupakan nilai yang menunjukkan munculnya respon analit yang lebih besar dari respon yang tidak diinginkan, maka respon analit harus tiga kali lebih besar dari respon baseline noise. Nilai LOD yang diperoleh adalah
0,43 $\mu \mathrm{g} / \mathrm{mL}$. Sedangkan batas kuantitasi (LOQ) digunakan untuk mengetahui kuantitasi terkecil dari analit dalam sampel yang masih dapat memenuhi kriteria cermat dan seksama. Respon analit harus menunjukan 10 kali lebih besar dari respon sinyal blanko (Harmita, 2004). Hasil perhitungan menunjukan nilai LOQ yang diperoleh adalah 1,47 $\mu \mathrm{g} / \mathrm{mL}$.

\section{Uji Ketepatan (Accuracy)}

Akurasi merupakan kedekatan hasil analis dengan kadar analit yang sebenarnya. Parameter akurasi adalah \% recovery. Recovery diperoleh dari persentase rata-rata kadar ibuprofen standar pada konsentrasi tertentu. Hasil $\%$ recovery dapat dikatakan baik jika memenuhi persyaratan rentang recovery yang diterima yaitu antara 80-120\% (Harmita, 2004). Hasil uji akurasi yang diperoleh pada penambahan ibuprofen baku $4 \mu \mathrm{g} / \mathrm{mL}$ dapat dilihat pada Tabel 3.

Tabel 3. Hasil uji akurasi

\begin{tabular}{ccc}
\hline Replikasi & Luas area & \% Recovery \\
\hline 1 & 94346 & 91,56 \\
2 & 95271 & 92,68 \\
3 & 90852 & 87,18 \\
Rata-rata & 94346 & 90,47 \\
\hline
\end{tabular}

Persentase perolehan kembali yang diperoleh adalah 90,47\% dengan kesalahan sistematik $9,53 \%$. Nilai ratarata perolehan kembali analit yang dikatakan baik adalah antara 80-120\% (Gandjar \& Rohman, 2007). Hasil tersebut menunjukkan bahwa \% perolehan kembali metode ini baik karena memenuhi persyaratan rentang \% perolehan kembali.

\section{Uji Keseragaman Bobot}

Uji keseragaman bobot dilakukan untuk mendapatkan bobot tablet yang seragam dan dari semua tablet yang ditimbang bobotnya tidak menyimpang dari ketentuan dalam Farmakope Indonesia Edisi III. Pada uji ini digunakan 20 tablet kemudian ditimbang satu per satu dan diperoleh bobot tablet rata-ratanya adalah $732,8 \mathrm{mg}$ untuk tablet merek dan 562,5 mg untuk tablet generik.

Penetapan Kadar Ibuprofen Tablet Merek dalam Plasma Darah Tikus Jantan Wistar

Hasil rata-rata \% kadar yang diperoleh dari setiap pengambilan larutan ibuprofen dari tablet merek dapat 
Penetapan kadar ibuprofen dalam tablet serta aplikasinya pada plasma...(Susanti, dkk)

dilihat pada Tabel 4, sedangkan untuk tablet generik dapat dilihat pada Tabel 5. Hasil rata-rata \% kadar yang diperoleh dari setiap pengambilan larutan

ibuprofen baik untuk tablet merek maupun generik memenuhi rentang yang diterima yaitu 90\%-110\% (Depkes, 1995).

Tabel 4. Hasil penetapan kadar tablet ibuprofen merek

\begin{tabular}{|c|c|c|c|c|}
\hline $\begin{array}{c}\text { Penambahan } \\
\text { lbuprofen }(\mathrm{mL})\end{array}$ & Luas Area & $\operatorname{Kadar}(\mu \mathrm{g} / \mathrm{mL})$ & Kadar (mg/tab) & Kadar (\%) \\
\hline \multirow[t]{3}{*}{ 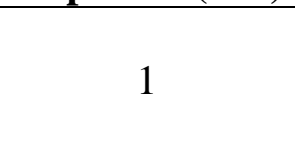 } & 211613 & 3,79 & 379 & 94,75 \\
\hline & 185508 & 3,27 & 327 & 81,75 \\
\hline & 225130 & 4,06 & 406 & 101,5 \\
\hline \multicolumn{4}{|c|}{ Rata-Rata } & 92,67 \\
\hline \multirow{3}{*}{0,8} & 179926 & 3,16 & 360 & 90 \\
\hline & 176141 & 3,09 & 352 & 88 \\
\hline & 184202 & 3.25 & 370 & 92,5 \\
\hline \multicolumn{3}{|c|}{ Rata-Rata } & & 90,17 \\
\hline \multirow{3}{*}{0,6} & 159958 & 2,76 & 386 & 96,5 \\
\hline & 163095 & 2,83 & 396 & 99 \\
\hline & 153836 & 2,64 & 369 & 92,4 \\
\hline \multicolumn{4}{|c|}{ Rata-Rata } & 95,96 \\
\hline
\end{tabular}

Tabel 5. Hasil penetapan kadar ibuprofen tablet generik

\begin{tabular}{|c|c|c|c|c|}
\hline $\begin{array}{c}\text { Penambahan } \\
\text { lbuprofen } \\
(\mathrm{mL})\end{array}$ & Luas Area & Kadar $(\mu \mathrm{g} / \mathrm{mL})$ & Kadar (mg/tab) & Kadar (\%) \\
\hline \multirow[t]{3}{*}{${ }^{2}$} & 185477 & 3,28 & 328,29 & 82,07 \\
\hline & 206577 & 3,69 & 369,33 & 92,33 \\
\hline & 216846 & 3,89 & 389,35 & 97,34 \\
\hline \multicolumn{4}{|c|}{ Rata-Rata } & 90,61 \\
\hline \multirow{3}{*}{0,8} & 164728 & 2,86 & 320,60 & 80,15 \\
\hline & 170448 & 2,98 & 334,06 & 83,52 \\
\hline & 178473 & 3.14 & 351,99 & 87,99 \\
\hline \multicolumn{4}{|c|}{ Rata-Rata } & 83,89 \\
\hline \multirow{3}{*}{0,6} & 159958 & 2,51 & 351,71 & 87,93 \\
\hline & 163095 & 2,36 & 330,69 & 82,67 \\
\hline & 153836 & 2,90 & 406,36 & 101,59 \\
\hline \multicolumn{4}{|c|}{ Rata-Rata } & 90,73 \\
\hline
\end{tabular}

\section{KESIMPULAN}

Dari hasil penelitian yang telah dilakukan dapat disimpulkan bahwa metode KCKT dapat digunakan untuk analisis ibuprofen tablet generik maupun merek dalam matriks plasma darah. Ibuprofen yang dianalisis memenuhi persyaratan batas persen kadar.

\section{DAFTAR PUSTAKA}

Ansel, H.C., 1985. Introduction to Pharmaceutical Dosage Forms. Lea \& Febiger, Philadelphia.

Depkes RI, 1995. Farmakope Indonesia, edisi IV. Departemen Kesehatan Republik Indonesia, Jakarta. 
Gandjar, I. G., Rohman, A., 2007. Kimia Farmasi Analisis. Pustaka Pelajar, Yogyakarta.

Miller, J.C dan Miller, J.N., 1991. Statistika untuk Kimia Analitik (Terjemahan) Suroso. ITB, Bandung.

Harmita. 2004. Petunjuk pelaksanaan validasi Metode dan cara perhitungannya. Majalah Ilmu Kefarmasian 1(3):117-134.
Katzung, B.G., 2001. Farmakologi Dasar dan Klinik, edisi ke-8. Salemba Medika, Jakarta.

Siswandono \& Soekardjo B. 2000. Kimia Medisinal, Jilid 1. Edisi II. Airlangga University Press, Surabaya.

Wiria, M.S.S., Suyatna, F.D., 2007. A comparative bioavailability study of two ibuprofen formulations after single-dose administration in healthy volunteers. Med J Indones, 16 (3):181-186. 